\title{
IMPLEMENTATION OF INNOVATIVE TECHNOLOGIES AT THE LANGUAGE LEARNING AT THE NEW UKRAINIAN SCHOOL
}

\author{
Natalia Dyka ${ }^{1}$ \\ Viktoria Mykytenko \\ Olena Shkirenko ${ }^{3}$
}

DOI: https://doi.org/10.30525/978-9934-588-15-0-7

\begin{abstract}
The article deals with the problem of implementation of innovative pedagogical technologies of language learning at the New Ukrainian School. The attention is dedicated to the phenomenon of integration of pedagogical technologies in achieving a specific educational goal. The degrees of the development of various aspects of the problem, which are studied in methodical, psychological literature and linguistics, have been analyzed. It is noted that in modern linguistics the problem of implementation of pedagogical technologies at the lessons of the Ukrainian language has been deeply developed. However, the social importance of mastering students' key competences, skills and knowledge of self-acquisition and assimilation of knowledge, world trends in the development of modern science, processes of updating the education system in Ukraine, as well as insufficient coverage of issues in modern linguistics has actualized the problem of finding effective ways to implement innovative technologies of language learning at the New Ukrainian School. The object, subject, aim and research objectives are clearly defined. The methodology of the research (theoretical methods include studying of normative documents and working on topical problems of general secondary education, analysis and synthesis of achievements of linguistic, psychological, pedagogical sciences on the problem of implementation
\end{abstract}

\footnotetext{
${ }^{1}$ Ph.D. in Pedagogy, Associate Professor, Head at the Department of Language and Literature, Institute of In-Service Training, Borys Grinchenko Kyiv University, Ukraine ${ }^{2} \mathrm{Ph} . \mathrm{D}$. in Pedagogy,

Methodist at the Department of Language and Literature,

Institute of In-Service Training, Borys Grinchenko Kyiv University, Ukraine

${ }^{3} \mathrm{Ph} . \mathrm{D}$. in Psychology,

Senior Lecturer at the Department of Language and Literature, Institute of In-Service Training, Borys Grinchenko Kyiv University, Ukraine

(C) Natalia Dyka, Viktoria Mykytenko, Olena Shkirenko
} 
of innovative technologies of language learning at the New Ukrainian School; comparison, classification and generalization of theoretical data; empirical methods comprise observations, conversations with teachers and students, questionnaires, analysis of lessons, writing and oral responses of students study and generalization of teachers' best practices in the process of implementing innovative technologies at language lessons). It has been found that the initial requirements for the implementation of innovative technologies of language learning at the New Ukrainian School are: necessities on the need to integrate different approaches to language learning in a comprehensive language school course; provisions on the need for an organic combination of different pedagogical technologies in language teaching at school; provisions on interdisciplinary and cross-curricular communication of language and, accordingly, opportunities for the formation of paradoxical and divergent thinking of students as the basis for a diverse, critical thinking personality. It is determined that the implementation of innovative learning technologies at school is carried out in the following areas: mastering linguistic terminology, key categories, spelling and punctuation rules, linguistic facts and phenomena regarding the features of the functioning of linguistic units in texts of different styles and genres of speech, etc.; implementation of cross-curricular and intra-subject connections, which contributes to the formation of a paradoxical type of students' thinking and implements the principles of openness and emergence of scientific knowledge. The linguo-didactic features of the implementation of innovative technologies of language learning at the New Ukrainian School are highlighted. Effective innovative technologies in general secondary education institutions have been characterized. The prospects of further research on specifying the course of integration processes between innovative learning technologies, development of specific methods and tactics for their implementation at the language lessons at school on the material of different language levels and units are determined.

\section{Introduction}

The problem of the implementation of innovative technologies at the Ukrainian language lessons is deeply elaborated in modern linguistics (O. Bilyaev, O. Goroshkina, N. Dyka, O. Karaman, S. Karaman, O. Melnichaiko, S. Omelchuk, M. Pentylyuk, K. Plysko, S. Potapenko, L. Skuratovska, R. Khrystianinova, G. Shelekhova, I. Yushchuk), however, 
some aspects of this issue have remained unexplored, and the specifics of the implementation of innovative technologies in the New Ukrainian School require further study, which predetermines the choice of the topic.

The object of study is the process of learning the language of students in the New Ukrainian School.

The subject of the research is the content, methods, techniques and forms of organization of educational activity aimed at the implementation of innovative technologies in the New Ukrainian School.

The purpose of the work is to highlight the implementation of innovative technologies of language learning at the New Ukrainian School.

Achieving this goal involves the following tasks:

1. To analyze the degree of development of various aspects of the problem, which are investigated in methodical, linguistic, psychological literature.

2. To distinguish linguo-didactic features of implementation of innovative technologies of language learning at the New Ukrainian School.

3. Describe effective innovative technologies in general secondary education institutions.

4. Identify prospects for further research.

The following methods were used to solve the research objectives:

- theoretical methods comprise the study of normative documents and works on topical problems of general secondary education, analysis and synthesis of achievements of linguistic, linguistic, psychological, pedagogical sciences on the problem of implementation of innovative technologies of learning the language at the New Ukrainian School, which made it possible to distinguish among them effective ones; theoretical modeling, on the basis of which linguo-didactic features of innovative technologies are substantiated; comparison, classification, systematization and generalization of theoretical data, which describes the peculiarities of implementation of the competence approach in general secondary education institutions;

- empirical methods contain observations, conversations with teachers and students, questionnaires, analysis of lessons, writing and oral responses of students, school documentation; studying and summarizing teachers' best practices in the process of implementing innovative technologies at language lessons. Thus, the social importance of students' mastery of key competences, skills and knowledge of self-acquisition and assimilation of knowledge, world trends in the development of modern 
science, processes of updating the education system in Ukraine, as well as lack of coverage in modern linguo-didactics actualized the problem of finding effective ways to implement effective means and technologies language lessons in modern school.

\section{Lingvodidactic features of the implementation of innovative technologies}

Global trends in the development of scientific knowledge have led to the process of reforming language education in Ukraine, its reorientation to the formation of a comprehensively skilled personality. Today's information society needs a multi-skilled specialist who is able to navigate the information flows freely, analyze the problem from different positions, produce creative ideas, have the skills and ability to communicate effectively. Transformational processes in the educational space of Ukraine contribute to the emergence of qualitatively new requirements for language training of modern students. The information society requires the formation of a comprehensively skilled personality capable of representing himself / herself through a high level of communication, which actualizes the problem of the development of the linguistic personality of the student. In our opinion, the specificity of the implementation of innovative pedagogical technologies of learning the language at the New Ukrainian School is of particular importance for solving this problem.

Any pedagogical technology is a set of methods, techniques and teaching aids. It should be noted that there are different opinions in linguistics training regarding the number of methods, techniques and teaching tools that a teacher should use in the educational process. In particular, the dictionary of teaching methods of Ukrainian language written by O. Kucheruk [5] has about 300 methods, and the encyclopedia of interactive teaching methods [7] contains about 100 ones. Of course, the teacher is not obliged to know each of these methods, but he or she must be informed about their existence and where to find them.

Features of the implementation of innovative technologies in language education are based on general didactic, linguistic, cognitive and specific principles of learning. Generally, they can be submitted as follows:

The foundation that creates the principles of learning is realized through a selection of methods, techniques and teaching aids, the peculiarities of which create a certain pedagogical technology. The most common language 


\section{GENERALDIDACTIC AND LINGO DIDACTIC PRINCIPLES OF TEACHING:}

- - personal, ethnocultural, integrative, emotional, creative, active cognitive orientation

\section{COGNITIVE PRINCIPLES OF LEARNING:}

- - principle of categorization (linear-step principle, principle of combination of analysis and synthesis in work with syntactic units of all levels, principle of logic, principle of hermeneutics)

- - principle of conceptualization (principle of orientation to the picture of the world principle of reliance on mechanisms of generation and perception of speech, principle of organization of the intemal lexicon)

Figure 1. Lingvo-didactic features of the use of methods, techniques and teaching aids

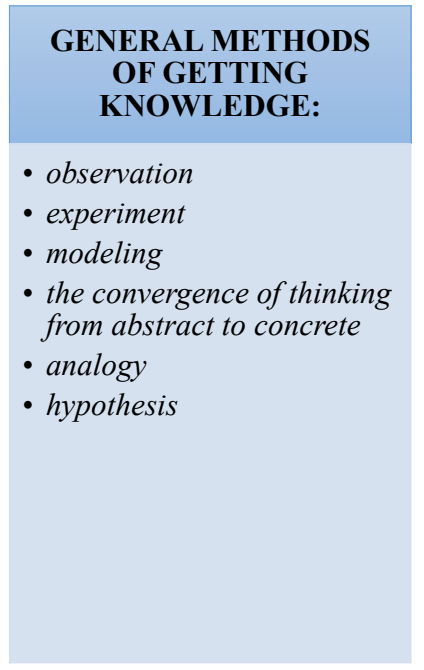

COGNITIVE TEACHING
METHODS:
- method of enlarging
didactic units
- partially searchable
- programmed learning
method
- "Linguistic observation"
- "linguistic analysis"
- "linguistic comparison"
- "linguistic experiment"
- method of conceptual
analysis
- method of working in the
creative field

Communicative teaching methods:

conversation, discussion, forum discussion, panel discussion, "dialogue of cultures" and others.

Figure 2. Language teaching methods 


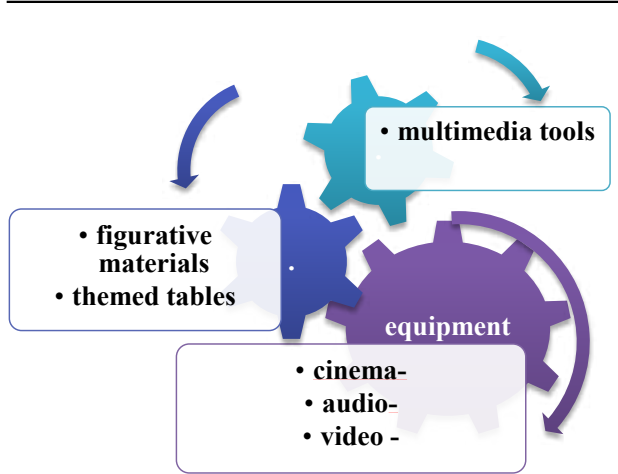

Figure 3. Language learning tools

teaching methods are as follows (Figure 2).

Modern language learning tools are important for the implementation of innovative technologies:

Language learning techniques vary constantly depending on the educational goal. Here is an example of cognitive and syntactic learning techniques:

One of them is video conferencing. Video

conferencing lets schools connect with classrooms all over the world, helping to break down cultural barriers. Students in different parts of the world can also use video conferencing to work collaboratively on a joint activity. Here again, this helps to provide a different perspective and helps pupils to understand varied cultural approaches and outlooks.

Video conferencing can be used to bring experts into the classroom quickly and easily. Such face-to-face time doesn't just help to develop communication skills, it also adds value and relevancy to lessons, and instills a deeper awareness of global issues.

School trips give students hands-on experiences, and through video conferencing, teachers can provide exposure to this style of learning from the comfort of the classroom. Students can visit world-renowned museums, without having to worry about finding additional funds.

Video conferencing brings a range of administrative and time-saving benefits to teachers. For example, parent-teacher conferences can be done online, helping to minimize scheduling conflicts, teacher meetings can be recorded and made available to staff who can't attend on the day, and even assemblies can be delivered directly to the classroom, reducing the time needed to move children to and from school halls.

The more we communicate via video conferencing and online chatting, the more online learning networks we create. As well as using these communities to help students to cooperate with each other, teachers will also develop collaborations and be able to share resources. 


\section{Syntactic and cognitive learning}

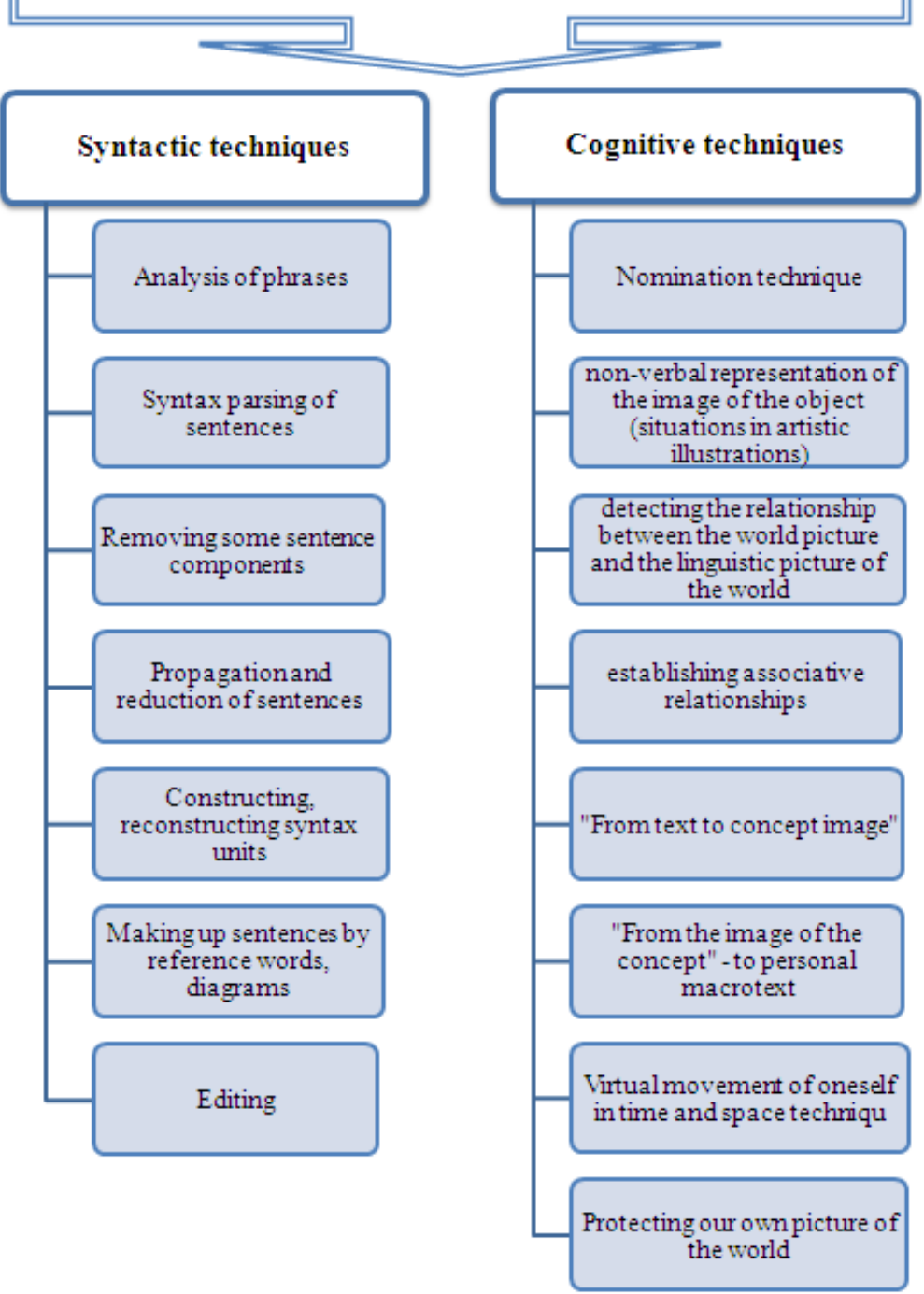

Figure 4. Cognitive and syntactic learning techniques 
Thus, a number of problematic issues, which are of priority in the Ukrainian language methodology, were identified, in particular the linguistic and didactic features of the content filling of innovative technologies, which are the basis of language teaching at school, and it was concluded that effective formation of a competent personality of the student is possible only on the basis of their complex application in pedagogical practice. Accordingly, the implementation of the integration of innovative technologies in the language learning process is considered possible under the following conditions:

- giving priority to language teaching in communicative principles, which will help develop skills to build and use different types of linguistic structures in speech, depending on the conditions of a particular communication situation;

- strengthening of functional and stylistic orientation in the consideration of linguistic units while studying theoretical material;

- the study of linguistic units in the unity of their content, form, function and interconnections with other linguistic units, which will contribute to the formation of a coherent linguistic picture of the world and a conscious mastery of the language;

- using a specially designed system of exercises and tasks based on cohesive texts of different styles, types and genres.

The effectiveness of forming a competent, competitive student will be greatly increased if these conditions are optimally combined and interpenetrated at language lessons.

The starting points for the implementation of innovative technologies of language learning at the New Ukrainian School, in our opinion, are:

- requirements on the need to integrate different approaches to language learning in the general school language course (in particular, personally oriented, competent, individual, communicative-activity, functionalstylistic, text-centric, synergistic, etc.);

- requirements for the need for an organic blend of different pedagogical technologies in language teaching at school (eg, personally-oriented, interactive, advance learning technology, research, design, etc.);

- requirements for interdisciplinary and cross-curricular communication of language and, accordingly, opportunities for the formation of paradoxical and divergent thinking of students as the basis for a well-developed, critically- 
minded individual (in particular, on the basis of a system of exercises containing specially selected texts illustrating the issue of a specific situation. It will allow to take into account individual abilities of students, to increase their level of educational motivation and cognitive activity).

Accordingly, integration of pedagogical technologies was determined as the basis for the organization of language training, which was done under the following conditions:

1) the necessity for the simultaneous formation of all structural components of the student's linguistic personality;

2) the requirement for an organic combination of the principles and approaches of learning that are different in conceptual basis;

3 ) using the phenomenon of integration of pedagogical technologies as a basic condition for ensuring the effectiveness of the holistic formation of a competent personality of the student.

In this regard, all components of the content of the language learning process (principles, approaches, pedagogical technologies, methods, techniques, tools, forms) should be aimed at solving a single task which is the formation of a well-skilled high-level learner with key competences.

Thus, by integrating pedagogical technologies in the process of language learning, we mean, on the one hand, the complex formation of key competences, among which priority is considered to be language, speech, socio-cultural and communicative; and, on the other, the implementation of language training on the conceptual principles of the complex above defined conditions.

We believe that the level of formation of key competences of students will increase significantly if:

- we teach Ukrainian language on the basis of interdisciplinary communication, taking into account the semantic characteristics of each learned phenomenon and peculiarities of its speech functioning;

- we use the integration of pedagogical technologies to teach theoretical material;

- we apply the optimal combination of theoretical information and practical exercises and tasks;

- we use different language styles and genres when learning a language;

- we build the educational process in accordance with the basic general scientific, general didactic, linguistic-didactic and specific principles. 
How to increase the efficiency of the educational process, to achieve high intellectual development of students, to ensure their personal selfdevelopment skills within the classroom system. Of course, this can be achieved to some extent by implementing modern innovative technologies in general secondary education institutions. The lessons should enthrall the students, stimulate their interest and motivation, teach independent thinking and develop creativity. The effectiveness and power of influencing the emotions and consciousness of students, of course, depends on the ability and style, after all, the work of a particular teacher.

According to our research, the implementation of innovative learning technologies at school should be conducted in the following areas:

- generalization and systematization at the higher level of the theoretical material studied: mastery of linguistic terminology, key categories, spelling and punctuation rules, linguistic facts and phenomena regarding the peculiarities of the functioning of linguistic units in texts of different styles and genres of speech, etc.;

- implementation of cross-curricular and inter-subject links, which contributes to the formation of a paradoxical type of thinking among students and implements the principles of openness and emergence of scientific knowledge.

Therefore, acquaintance of students with the specifics of each language level, stylistic qualities of linguistic constructions of different types and types will contribute to the formation of grammatical competence of students in the New Ukrainian School. The use of innovative technologies will help to realize students' mental activity, their readiness to overcome difficulties in the process of solving difficult tasks, to develop their creative activity and imagination, to promote intellectual potential and ability to convey their own thoughts.

\section{General characteristics of innovative technologies at school}

Nowadays, education in Ukraine is characterized by a number of reforms that are being implemented at the regulatory and legal level through the approval and implementation of the Concept of a New Ukrainian School, which defines priority areas for the development of education, outlines the predicted result, which is implemented through the formation of key competences among students and so on. 
In addition, in the general aspect of the characteristics of the problem, it is worth noting the transition from the immense consumption of information or knowledge to its selection and filtering. It becomes valuable to focus attention, filter out unnecessary, the ability to be «here and now», make informed decisions. And so the top 10 priority skills in 2020 include critical thinking, empathy, and creativity. Popular in school is the Socratic teaching method, or «philosophy for children», which teaches everyone to concentrate on making judgments. Creativity becomes a human advantage in competition with robots and artificial intelligence.

The concept of «error» is fundamentally rethought. Today, a mistake is a valuable experience, not a reason to downplay an estimate. We have an unknown future ahead of us, that is why the modern world is a world of experimentation and invention where we cannot do without mistakes and trials.

The trend of our time is freedom of choice. We can choose the time of study, the pace of learning the materials and textbooks. This is assisted by technologies and techniques. They are blended learning, distance learning, e-learning, Massive Open Online Courses. Introverts or children with physical disabilities or financial problems can study online.

Content is becoming more important nowadays, educators are more valuable than schools, and skills are more important than a diploma. The purpose of learning has changed. There is not the transfer of knowledge, but the skills for life, in order to be happy. Teachers, mentors, and coaches replace teachers. The most effective way of learning is asking and answering questions. The coach stimulates thinking, directs, streamlines the process, but the student seeks answers. Now, children are not an empty vessel that needs to be filled, but they are like seeds that already have a program in them. There is need to fertilize the soil and water it. Everyone can learn from wise people, but we will build your own path when we listen to ourselves, to our hearts. Gregory Skovoroda [8] said about that: «If you know yourself you will know the whole world.»

The UK Open University has released a report on Innovation in Pedagogy 2014 [9]: "Learning New Forms of Teaching, Learning and Assessment". According to Western colleagues, the following aspects of education will be actively developed and implemented in the near future:

1. Massive open social education. Broadcasting knowledge and experience will be organized through social networks and professional 
communities. The creation of joint training projects and products, consultations, virtual meetings and more will be relevant.

2. Building a curriculum for students based on analytical data (adaptive learning, curriculum design). The training should be adapted to the unique «trajectory of learning» of the student. which can be obtained and constantly adjusted with the help of special analytical tools. Adaptive learning technologies still remain closed to most educational institutions because of the high cost of development, but more and more tools for accurate tracking of learning success will be introduced into everyday learning.

3. Flipped classroom. Inverted learning is a form of blended learning that allows you to «turn over» the ordinary class as follows: instead of homework, students watch short video lectures online. They go through theoretical material on their own and all classroom time when the teacher is close together is used for sharing practical tasks. It is an active form of learning that allows all students to be involved at the lesson.

4. BYOD. Bring your own devices. It provides the ability to use our own mobile devices to solve different educational and professional tasks at any time, regardless of location.

5. Forming the ability to learn (metacognition: learning how to become an effective learner). More and more students are thinking about how they are learning, how to study properly, and what needs to be done to learn better. Half of the professions can be changed in 20 years. And the world itself is constantly changing, so the ability to learn becomes a very urgent problem.

6. Dynamic evaluation. In this approach, assessments are not for a single task, but for progress in the study of the subject as a whole. The student is evaluated not by class, but by his or her progress. The difference between dynamic assessment and statistical evaluation is: 1) the focus of dynamic assessment is on future development, while statistical evaluation is on past achievements; 2) dynamic assessment gives feedback to the student during the assessment process. Dynamic assessment is constantly criticized, but the main conclusion that can be drawn from this assessment is how well the student is progressing.

It should be noted that under the terms of the New Ukrainian School Concept, the so-called formative assessment is being actively implemented. 
The Methodological Recommendations provided by the Ministry of Education and Science of Ukraine [6] regarding the formative assessment of students emphasize that such assessment provides for the tracking of students' personal development and the course of their learning experience and competences.

Formative assessment is an interactive assessment of students' progress that enables the teacher to adapt the educational process. The use of formative assessment allows you to track the personal progress of the child, the course of mastering the educational material and to build an individual educational trajectory of the individual. Formative assessment assesses the learning process of students, not the outcome.

An integral part of the assessment process is the formation of students' ability to self-assess their own progress. Guidelines for observation and assessment are the general and specific expected results that are required to organize the observation of a student's educational progress; discussing students' educational progress individually with their parents or with people who take care of a child instead of them.

Formative assessment aims are to support students' educational progress; to develop confidence in a child, emphasizing the strengths, not mistakes, diagnosing achievement at each stage of learning; identify problems in a timely manner and prevent them from staining; support the desire to learn and strive for the greatest possible results; prevent fear of making a mistake.

Assessment of students' achievements should be directed to the formation of positive self-esteem. It is important not to confront children with one another. It should be stimulating to compare work (answers, actions, etc.) with how a child has worked before. It is advisable to focus only on the positive dynamics of achievement of a student. Difficulties in learning should be discussed with a student individually in order not to create a situation of collective disrespect for a child.

At the same time, it is advisable to teach children mutual appreciation, while forming the ability to correctly express the opinion of a classmate, give advice on how to improve it. It activates the educational work, promotes the development of critical thinking, the formation of an adequate attitude to the comments, recommendations, strengthens the sociability and sense of importance of everyone in the team. 
7. Event-based education. You can study during educational competitions, festivals, quizzes for a short period - a day or two. These events often create the atmosphere of a festival and bring together competitors. Master classes and individual lessons can be held within this event.

8. Storytelling is learning through stories. A person always remembers interesting stories. Why not to make a fascinating story? Now there are many tools available on the web for creating timelines, animations and comics.

9. «Key concepts». The key concept is described as «why it matters and how it can be put into practice.» The design of the curriculum around key concepts can optimize the structure of the learning process, facilitate dialogues between students, and assist them in mastering complex topics. The significance of threshold concepts is that they provide a multidisciplinary approach to learning that is based on a thorough understanding of complex concepts.

10. Bricolage. The translation of «bricolage» from French means «mastering», that is, working creatively with some tools and resources. There are two options for using bricolage. The first is that people learn to improvise with different materials. For example, when playing with dolls, children learn how to treat others, trying on different social roles. Two chairs and a blanket can become a home and a pencil a medical injection. The second is the creation of content from what is at hand in this class, school, audience. The bottom line is that you can build learning without manuals, improvising with materials, forms, ideas.

Despite the presence of a large number of new technologies, interactive technologies remain particularly relevant in the language learning process. The essence of interactive learning is that the educational process takes place under the condition of continuous, active interaction of all students. It is co-teaching, (collective, group, co-operative learning) where both a student and a teacher are equal, equal subjects of learning, understand what they do, reflect on what they know and what they are able to do.

The gamification of the educational process has recently become particularly relevant. Among the interactive technologies are imitations, simulations, business and role-playing games. Imitations are called procedures with the implementation of certain simple known actions that reproduce any phenomena of environmental reality. Simulation participants 
respond to a specific situation within a given program by clearly following the instructions. During imitation, students receive clear operating instructions. Pupils perform actions individually.

More complex imitation games are called simulations. These are teacher-created situations in which students copy, in a simplified form, procedures related to the activities of public institutions that exist in real life. When preparing students for a simulation, the teacher should not only share roles, but also clarify with each performer the sequence of his actions and statements.

Role-play imitates the reality of assigning roles to participants and giving them the opportunity to act as if it's a reality. Everyone in the role-playing game must have a clear understanding of the meaning of their role and the purpose of the role-playing game in general. The purpose of role-playing is to determine the attitude to a particular life situation, to gain experience through play, to help learn through experience and feelings. Role playing was used to gain specific skills and knowledge.

In the book written by N. Volkova «Pedagogy» [2] is an attempt to classify non-standard lessons, which, in our opinion, are based on the diversity of innovative technologies:

1) Content-oriented lessons (lessons-seminars, lessons-conferences, lessons-lectures);

2) Integrative lessons (complexes, panorama lessons);

3) Cross-curricular lessons;

4) Competition lessons (auction lessons, tournament lessons, quiz lessons, competitions.);

5) Public Knowledge Review Lessons (Creative Reporting Lessons, Classroom Tutorials, Impromptu Exams, Consultation Lessons, Mutual Lessons, Consulting Lessons);

6) Communication lessons (lessons-oral journals, lessons-dialogues, lessonsreports, lessons-panoramas, lessons-contradictions, lessons-paradoxes);

7) Lessons theatrical (lessons-performances, lessons-concerts, film lessons, didactic theater);

8) Travel lessons, study lessons (search lessons, reconnaissance lessons, lab-study lessons, expeditionary lessons, correspondence lessons, research lessons);

9) Lessons with diverse composition of students; 
10) Business lessons, role-playing games (court-lessons, dissertationdefense lessons, lessons-»Investigation is conducted by experts», improvisation lessons, lessons-illustrations);

11) Dramatic lessons (dramatic play, story dramatization, pantomime work, shadow plays with dolls and puppets, all kinds of unprepared drama activity where formal drama is created by the participants of the game);

12) Psycho-training lessons.

All outlined innovative pedagogical technologies are implemented in language education through the latest teaching methods, among which are:

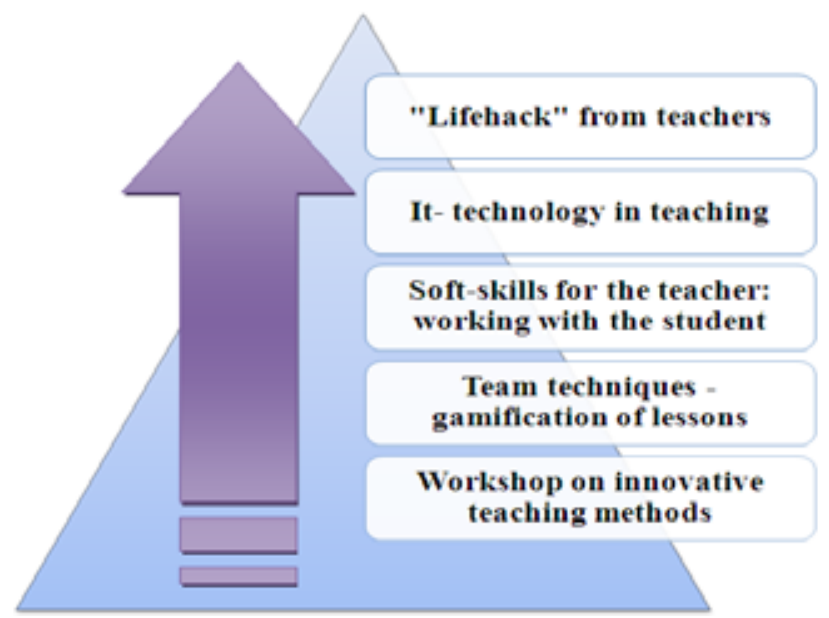

Figure 5. Outlined innovative pedagogical technologies

Therefore, despite the large number of available innovative pedagogical technologies, we consider the most effective use of the phenomenon of the integration in pedagogical practice is, the optimal combination, which will cause synergetic effect and lead to the realization of the positive effects of each individual technology, minimizing the obvious ones. In the process of learning a language the use of this phenomenon allows you to diversify the educational process, making it more dynamic, psychologically balanced. It shapes students' self-development motivation, improves their organizational skills, creativity and also it promotes the teacher's creative self-realization. 


\section{Conclusions}

Changes in activity in the classroom, caused by the use of innovative technologies, require the student to «advance in an unknown space»: in his or her life experience, neither new rules of activity, nor algorithms of action, nor a new status in a new situation are presented. In the past a student completely obeyed the teacher, and now he is expected to be active, expressing thoughts, ideas, doubts, solving tasks and problems, which often have several correct answers. The rules of interaction of a teacher with students are subject to revision, as well as the norms of self-esteem, ways of analyzing one's own activity and its results. All these aspects have to be discovered, defined and built by a student.

So, in order for the process of adaptation to new technologies to start and pass successfully, the student needs to go beyond the "comfort zone" that was earlier, to expand it, to feel safe in the new situation. Overcoming fears, uncertainty about a new situation, understanding and accepting new requirements will in turn influence the effectiveness of learning activities. For successful implementation of innovative pedagogical technologies in the language learning process, we consider it necessary to use the phenomenon of integration of the latest technologies, which is, in our opinion, due to the skillful combination of elements of different technologies in order to achieve a single educational goal.

We see the prospects for further research in specifying the course of integration between innovative learning technologies, developing specific methods and tactics for their implementation in the language lessons at school on the basis of different language levels and units.

So, in order for the process of adaptation to new technologies to start and pass successfully, it is necessary for a student to go beyond the previous "comfort zone" to expand it, to feel safe in the new situation.

Overcoming fears, uncertainty about a new situation, understanding and accepting new requirements will influence the effectiveness of learning activities. For successful implementation of innovative pedagogical technologies in the language learning process, we consider that it is necessary to use the phenomenon of integration of the latest technologies. It can be done with the help of skillful combination of elements of different technologies in order to achieve a single educational goal. 
We see the prospects for further research in specifying the course of integration between innovative learning technologies, developing specific methods and tactics for their implementation at the language lessons at school on the basis of different language levels and units.

\section{References:}

1. Bibik N.M. (2015). Perevaghy i ryzyky zaprovadzhennja kompetentnisnogho pidkhodu v shkiljnij osviti [Benefits and risks of introducing a competent approach in school education]. Ukrainian Pedagogical Journal, vol. 1, pp. 47-58. (in Ukrainian)

2. Volkova N.P. (2012). Pedahohika [Pedagogy]: navch. posib. 4-te vyd., ster. Kyiv: Akademvydav, p. 615. (in Ukrainian)

3. Dyka N.M., Ghlazova O.P. (2018). Nova paradyghma pisljadyplomnoji pedaghoghichnoji osvity: realizacija kompetentnisnogho pidkhodu [A new paradigm of postgraduate pedagogical education: realization of the competent approach]. Neperervna profesijna osvita: teorija i praktyka (Serija: Pedaghoghichni nauky). Vypusk 3-4 (56 -57), pp. 14 -20. DOI: 10.28925/1609-8595.2018(3-4)1420 (in Ukrainian)

4. Kontseptsiia Novoi ukrainskoi shkoly [Concept of the New Ukrainian School]. Retrieved from: https://mon.gov.ua/storage/app/media/news/\%D0\%9D \%D0\%BE\%D0\%B2\%D0\%B8\%D0\%BD\%D0\%B8/2018/12/12/11/20-11-2018rek viz.pdf (accessed: 30.10.2019). (in Ukrainian)

5. Kucheruk O.A. (2010). Metody navchannia ukrainskoi movy v zahalnoosvitnii shkoli: slovnyk-dovidnyk [Methods of teaching Ukrainian in a comprehensive school]. Zhytomyr: Ruta, p. 184. (in Ukrainian)

6. Metodychni rekomendatsii shchodo formuvalnoho otsiniuvannia uchniv [Guidelines for formative assessment of students] / Do lystiv MON vid 18.05.2018 № 2.2-1250 ta vid 21.05.2018 № 2.2-1255. URL: https://mon.gov.ua/ua/osvita/ zagalna-serednya-osvita/metodichni-rekomendaciyi; URL: https://resourced.prometheanworld.com/use-video-conferencing-classroom/ (accessed: 30.10.2019). (in Ukrainian)

7. Pometun O.I. (2007). Entsyklopediia interaktyvnoho navchannia [Interactive learning encyclopedia]. Kyiv, p. 143. (in Ukrainian)

8. Skovoroda Hryhorii: obraz myslytelia [Skovoroda Hryhorii: the image of the thinker] / NAN Ukrainy, In-t filos.; uporiad. V.M. Nichyk [ta in]; red. V.I. Shynkaruk, Stohnii I.P. Kyiv, 1997, p. 453. (in Ukrainian)

9. Sharples, M., Adams, A., Ferguson, R., Gaved, M., McAndrew, P., Rienties, B., Weller, M., \& Whitelock, D. (2014). Innovating Pedagogy 2014: Open University Innovation Report 3. Milton Keynes: The Open University. 